\author{
DUMLUPINAR ÜNIVERSITESI SOSYAL BİLIMLER DERGISİ \\ DUMLUPINAR UNIVERSITY JOURNAL OF SOCIAL SCIENCES \\ E-ISSN: 2587-005X http://dergipark.gov.tr/dpusbe \\ Dumlupinar Üniversitesi Sosyal Bilimler Dergisi, 67, 238-251; 2021 \\ DOI : 10.512901/dpusbe.827939
}

Araştırma Makalesi / Research Article

\title{
THE EFFECTS OF ECONOMIC, FINANCIAL AND POLITICAL RISKS ON CDS PREMIUM OF TURKEY
}

\author{
Vasıf ABİOĞLU ${ }^{1 *}$ \\ Munise Ilıkkan ÖZGÜR ${ }^{2}$ \\ Esra SOYU ${ }^{3}$
}

\begin{abstract}
The purpose of this study is to analyze the effects of economic, financial and political risks on CDS premium of Turkey. For this purpose, we examine asymmetric effects of economic, financial and political risk variables on Turkey's CDS by employing nonlinear autoregressive distributed lag model for the period 2000:10-2020:06. Our findings are two-fold. First, we find that both economic and financial risks have asymmetric effects on CDS premium, while political risks have symmetric effect on CDS. Second, we find that increases in financial risks raise CDS premium more than that of economic risks, while decreases in economic risks reduce CDS premium more than that of financial risks. The empirical results imply that economic reforms appear to be more efficient than the financial recovery measures in reducing CDS premium of Turkey.
\end{abstract}

Keywords: CDS, Economic risk, Financial risk, Political risk, NARDL

JEL Codes: E44, F34, G15

\section{İKTISADİ, FINNANSAL VE POLITTIK RİSKLERİN TÜRKIYYE CDS PRIMMINE ETKILLERI}

\begin{abstract}
$\ddot{\mathbf{O} z}$
$\mathrm{Bu}$ çalışmanın amacı ekonomik, finansal ve politik risklerin Türkiye CDS primine etkilerini araştırmaktır. Bu amaçla, NARDL modeli kullanılarak 2000:10-2020:06 döneminde ekonomik, finansal ve politik risklerin Türkiye CDS primine asimetrik etkileri incelenmektedir. Analizden iki önemli sonuç çıkmaktadır. İlk olarak, elde edilen bulgulara göre, ekonomik ve finansal risklerin CDS primi üzerinde asimetrik etkileri bulunurken, politik risklerin CDS primi üzerinde simetrik etkisi bulunmuştur. İkinci olarak, finansal risklerdeki artışların CDS primini yükseltmesi ekonomik risklerdeki artışların CDS primini yükseltmesinden daha fazla iken, ekonomik risklerdeki azalışların CDS primini düşürmesi finansal risklerdeki azalışların CDS primini düşürmesinden daha fazla olmaktadır. Ampirik analiz sonuçlarına göre, ekonomik reformlar CDS primini düşürmede finansal reformlardan daha etkili olmaktadır.
\end{abstract}

Anahtar kelimeler: CDS primi, Ekonomik risk, Finansal risk, Politik risk, NARDL

JEL Kodları: E44, F34, G15

\footnotetext{
${ }^{1}$ Dr. Öğr. Üyesi, Aksaray Üniversitesi, İIBF, İktisat Bölümü ORCID 0000-0002-8217-0702

* Sorumlu yazar (Corresponding Author): vabiyev@aksaray.edu.tr

${ }^{2}$ Doç. Dr., Aksaray Üniversitesi, İIBF, İktisat Bölümü ORCID 0000-0002-8711-3264

${ }^{3}$ Öğr. Gör. Aksaray Üniversitesi, Muhasebe ve Vergi Uygulamaları Bölümü, ORCID 0000-0003-1614-0967

Başvuru Tarihi (Received): 18.11.2020 Kabul Tarihi (Accepted): 27.01.2021
} 


\section{Introduction}

Due to the increasing globalization in the world, developments in areas such as economy, finance and politics have a profound effect on countries. In the globalization process, with the rapid and easy movement of capital in the markets, the importance of credit rating agencies has increased. Credit rating agencies such as Standard \& Poor's, Moody's and Fitch have a huge impact on the economy of a country. However, after the Asian Crisis that emerged in the second half of 1997 and the global financial crisis that started in America in the last quarter of 2007 and then affected the whole world, rating agencies and their ratings have become a frequent subject of discussion (Günal, 2019). In particular, credit rating agencies have been criticized for reasons such as failing to make objective assessments, incurring rating errors, working inefficiently, using methodologies that are not clear and poor accuracy in their ability to predict a crisis (Ryan, 2012; Alexe\& Lejeune, 2003; Kutuk \& Okur, 2020; Tutar, Tutar \& Eren, 2011).

Based on these negativities, other tools have emerged to provide more up-to-date, transparent and reliable information regarding the credit risk of a country. The most prominent of these tools is the one of the most important credit derivatives, Credit Default Swap (CDS) premium. CDS, in its narrowest definition, is a financial insurance contract that enables the effective management of credit risk. More broadly, a CDS is a loan derivative instrument that protects the creditor's money in return for a certain amount in case of default of a reference asset. Also, a CDS is a contract where the protection seller undertakes to pay the credit risk of the protection buyer partially or completely in return for a certain amount to be paid (CDS premium) if a credit risk in terms of the reference asset arises. CDS premium is often called "spread" in financial markets. The CDS spread is perceived to be an indicator of the credit quality of any single reference entity. A CDS's reference entity may be a bond issuing private corporation or government. Hence, these "spreads" reflect the market's view about the solvency of a country. CDS spreads are high when a default is likely to occur, and when the risk premium for bearing sovereign credit risk is high, and vice versa.(Kunt \& Taş, 2008; Ashcraft \& Santos, 2009; ECB, 2009; Fontana \& Scheicher, 2010; Raunig, 2018).

The CDS premium, which is the most practical way for a country to see its credit risk, became one of the leading indicators especially after the 2008 financial crisis period. In addition, it has become one of the favorite tools of providing information about the financial markets and measuring debt payment capabilities (Yenisu \& Yenice, 2018). Because changes in economic, financial and political risks directly and indirectly affect the CDS market, CDS becomes a parameter scrutinized by international investors (Bozkurt \& Kaya, 2018). So, changes in CDS reflects sentiment or forward-looking beliefs of these investors. These investors are directly or indirectly affected by the risks in the countries they intend to invest in (Ayaydın, Pala \& Barut, 2016).

The main purpose of this study was to examine the impact of economic, financial and political risks on CDS premiums in Turkey. The literature on economic, financial and political risks mainly focuses more on the effects of those risks on foreign direct investments, economic growth, current account deficit and credit rating agencies. Therefore, the number of studies analyzing the effects of economic, financial and political risks on CDS premiums is limited. Examples of studies that are closely related to the subject are given below.

Brandorf \& Holmberg (2010) examined the effects of changes in macroeconomic variables of PIIGS countries on the CDS spreads within the PIIGS countries for the period 2004Q1-2009Q3. They found that while an increase in public debt increased the CDS premium, the most effective variable on CDS was unemployment and the least effective variable was inflation. Balding (2011) examined the relationship between CDS pricing and elections in 13 emerging market economies for the period 2004-2007 and found that elections had statistically significant effect

On CDS pricing. Longstaff, Pan, Pedersen \& Singleton (2011) investigated the nature of CDS by examining the relationship between CDS spreads of 26 countries and country-specific factors of 
those countries and the relationship between CDS spreads and global financial variables. They found that although local stock market returns, exchange rates and foreign reserves had an effect on the CDS spreads, US stock markets and US bond interest rates had much higher effect on the CDS spreads of those countries. Plank (2012) analyzed the effect of CDS premiums of six countries and found a high correlation between CDS premiums and the foreign debt solvency of countries. Aizenman, Hutchison, \& Jinjarak (2013) examined the relationships between CDS spreads and fiscal space and some macroeconomic variables for 5 countries over the period 20052010. They find that the T-Bill spread, trade openness, external debt and inflation have an influence on the CDS spreads. Wisniewski \& Lambe (2015) investigated how changes in Economic Policy Uncertainty (EPU) might affect the CDS spread index for US and Europe over the period 2006-2014. They found that short-term shocks in political risk have statistically significant effects on CDS spreads. Başarır \& Keten (2016) examined short and long run relationships between CDS premium, stock indexes and exchange rates for 12 emerging market economies using monthly data for the period 2010-2016. The findings indicate that there is a bidirectional causality relationship between CDS and stock indexes and a unidirectional causality effect from CDS premium to exchange rates. However, a long run relationship is not found between the variables. Liu \& Zhong (2017) studied the effect of political uncertainty on individual firm's credit risk for 30 countries using monthly data over the period 2003-2012. Single-name CDS spreads were used to measure the credit risk of individual firms. They find that political uncertainty affects the credit risk of individual firm. Raunig (2018) considers 16 major economies to examine whether economic policy uncertainty helps to explain the variability of CDS spreads for the period 2008-2017. He finds strong support for a positive link between EPU and a country's CDS volatility. Lee \& Hyun (2019) investigated whether good and bad news has an asymmetric effect on CDS using data of 405 firms over the period 2003:01-2012:11. According to the findings, negative jumps have stronger influences on CDS spreads than positive jumps. Huang, Lin, \& Yang (2019) investigated whether the qualities of political, legal and regulatory institutions affect the CDS premium for 70 countries over the period 2000-2015. According to the research results, it was concluded that high corporate quality is associated with lower country risk which is suggesting that institutional quality has a role in explaining sovereign CDS spreads.

Ersan \& Günay (2009) tested whether the closure case against the ruling party in March 2008 in Turkey has a statistically significant effect on Turkey's CDS using daily data for the period 20042009, and they found no significant relationship. Kilc1 (2017) analyzed the cointegration relationship between economic and financial risk element sand CDS premiums in Turkey using monthly data over the period 2010-2015. As a result of the analysis, a long-term relationship was found between CDS premium and financial performance indicators. Atasever (2017) examined the relationship between Turkey's CDS premium, central bank reserves, domestic interest rate, dollar rate, bond interest rate, BIST100 index closing prices and election periods by VAR method using monthly data for the period 2010-2016. According to the analysis, the CDS variable in the short term is determined by exchange rate and bond interest rate, while the central bank reserve and stock market closing index are affected by the CDS premium. Furthermore, among all the variables, only the CDS variable is affected by election periods. Bozkurt\& Kaya (2018) studied the effect of good and bad news in the geography of the Arab Spring, namely in Iraq, Iran and Syria which are countries bordering Turkey, on the CDS premiums Turkey over the period 20102013. The study concluded that only good and bad news from Iran had an impact on Turkey's CDS premiums. Akyol \& Baltaci (2018), examined what domestic and global variables affected Turkey's CDS premiums using monthly data for the period 2006-2015. According to the study, local variables affecting CDS premiums in Turkey are real interest rates, BIST100 index returns, current account balance, portfolio investments and inflation rates, while the global variables affecting CDS premiums are the VIX, MSCI-Europe index, FED interest rates, oil prices and US economic/monetary policy uncertainties. Ulusoy \& Kendirli (2019) analyzed the effects of terrorist 
attacks in Turkey on the VIX fear index, the Borsa Istanbul 100 Index and its reflection on the CDS over the period 1997-2017. According to the results of the study, terrorist incidents in Turkey are reflected in the VIX fear index as slowly and delayed. In addition, it was determined that the fear index was low just before terrorist events, and went into a sudden accelerated increase immediately after an event. Furthermore, the effects of terrorist events on CDS in Turkey are manifested after the sixth day.

We employ nonlinear autoregressive distributed lag (NARDL) model to examine asymmetric effects of economic, financial and political risk variables on Turkey's CDS for the period 2000:102020:06. Our findings are two-fold. First, we find that both economic and financial risks have asymmetric effects on CDS premium, while political risks have symmetric effect on CDS. Second, we find that increases in financial risks raise CDS premium more than economic risks that increase the CDS premium, while decreases in economic risks reduce CDS premium more than the financial risks that reduce the CDS premium.

The paper is structured as follows, Section 1 develops econometric methodology, Section 2 describes data and the empirical results, and Section 3 concludes.

\section{Methodology}

The linear ARDL model proposed by Pesaran and Shin (1999) and Pesaran et al. (2001) takes the following form:

$$
\Delta y_{t}=\rho y_{t-1}+\theta x_{t-1}+\sum_{i=1}^{p-1} \gamma_{i} \Delta y_{t-i}+\sum_{i=0}^{q-1} \varphi_{i} \Delta x_{t-i}+e_{t}
$$

where $y_{t}$ is the dependent variable, $x_{t-1}$ is a $k \times 1$ vector of regressors, $\rho$ and $\theta$ coefficients represent long-run parameters and $\gamma_{i}$ and $\varphi_{i}$ coefficients represent the short-run parameters respectively. The $e_{t}$ is the i.i.d. error term.

Shin et al. (2014), introduce the NARDL model which decomposes the vector of regressors $x_{t}$ into positive and negative partial sums.

$$
x_{t}=x_{0}+x_{t}^{+}+x_{t}^{-}
$$

where $x_{t}^{+}$and $x_{t}^{-}$are partial sum processes of positive and negative changes in $x_{t}$ :

$$
x_{t}^{+}=\sum_{j=1}^{t} \Delta x_{j}^{+}=\sum_{j=1}^{t} \max \left(\Delta x_{j}, 0\right), x_{t}^{-}=\sum_{j=1}^{t} \Delta x_{j}^{-}=\sum_{j=1}^{t} \min \left(\Delta x_{j}, 0\right)
$$

In this case, the asymmetric long-run regression can be written as follows:

$$
y_{t}=\beta^{+} x_{t}^{+}+\beta^{-} x_{t}^{-}+u_{t}
$$

Where, $\beta^{+}$and $\beta^{-}$represent long-run parameters associated with the positive and negative changes in $x_{t}$, and $u_{t}$ denotes deviations from the long-run equilibrium. Following Shin et al. (2014), the NARDL model can be written as follows:

$$
\Delta y_{t}=\rho y_{t-1}+\theta^{+} x_{t-1}^{+}+\theta^{-} x_{t-1}^{-}+\sum_{i=1}^{p-1} \gamma_{i} \Delta y_{t-i}+\sum_{i=0}^{q-1}\left(\varphi_{j}^{+} \Delta x_{t-j}^{+}+\varphi_{j}^{-} \Delta x_{t-j}^{-}\right)+e_{t}
$$


where, $\varphi_{j}^{+}$and $\varphi_{j}^{-}$are the short-run adjustment coefficients to positive and negative changes in $x_{t}$. In order to test an asymmetric long-run relationship among the levels of the $y_{t}, x_{t}^{+}$and $x_{t}^{-}$, Shin et al. (2014) propose F-statistic ( $F_{P S S}$ ) developed by Pesaran et al. (2001) for the joint null $\rho=\theta^{+}=\theta^{-}=0$ in equation (4). Thus, $F_{P S S}$ tests the joint null hypothesis of no cointegration against the alternative of cointegration. Wald test can be employed to test for long and short run asymmetries in equation (4). By employing Wald test, the long-run asymmetry can be tested by testing the null hypothesis of $\beta^{+}=\beta^{-}$, where $\beta^{+}=-\frac{\theta^{+}}{\rho}$ and $\beta^{-}=-\frac{\theta^{-}}{\rho}$ respectively, while short-run asymmetry can be tested by testing the null hypothesis of $\sum_{i=0}^{q-1} \varphi_{i}^{+}=\sum_{i=0}^{q-1} \varphi_{i}^{-}$.

We can also derive the asymmetric dynamic multipliers associated with unit changes in $x_{t}^{+}$and $x_{t}^{-}$on $y_{t}$. The cumulative dynamic multiplier effects of $x_{t}^{+}$and $x_{t}^{-}$on $y_{t}$ can be evaluated as follows:

$m_{h}^{+}=\sum_{j=0}^{h} \frac{\partial y_{t+j}}{\partial x_{t}^{+}}$and $m_{h}^{-}=\sum_{j=0}^{h} \frac{\partial y_{t+j}}{\partial x_{t}^{-}}$

where $(h=0,1,2, \ldots$.$) . If h \rightarrow \infty$, then $m_{t}^{+} \rightarrow \beta^{+}$and $m_{t}^{-} \rightarrow \beta^{-}$.

\section{Data and Empirical Results}

In this paper we study the effects of economic, financial and political risks on Turkey's CDS using monthly data for the period 2000:10-2020:06. The data for economic, financial and political risks have been obtained from the ICRG, while the data for CDS have been obtained from the Bloomberg. Because ICRG presents comprehensive risk structure for a country with ratings for its economic, financial and political risks, most authors used the ICRG data in their research (Howell \& Chaddick, 1994; Erb, Harvey and Viskanta, 1996; Assane \& Grammy, 2003; Harvey, 2004; Hoti, 2005; Busse \& Hefeker, 2007; Lehkonen \& Heimonen, 2015; Nawaz, 2015; Hakimi \& Hamdi, 2017; Asif \& Majid, 2018; Aziz, 2018; Filippou, Gozluklu \& Taylor, 2018; Kirikkaleli, 2020; etc.). Economic, financial and political risk ratings provided by ICRG are scored between 0-50, 0-50 and 0-100, respectively (for more information see, Howell, 2011). In each case, the risk increases as the risk score approaches zero, and the risk decreases as the risk score increases. Due to the possibility of causing confusion in the interpretation of econometric findings, we divided economic, financial and political risk scores by one. Thus, increases (decreases) in risk scores indicate that the relevant risks have increased (decreased) in Turkey. As a result, in this study, the resulting economic, financial and political risks are represented by ERR, FRR and PRR respectively. Table 1 presents a summary of the data used for econometric analysis. 
Table 1: Summary of the Data

\begin{tabular}{lll}
\hline \multicolumn{1}{c}{ Symbol } & \multicolumn{1}{c}{ Variable } & \multicolumn{1}{c}{ Database } \\
\hline CDS & Credit Default Swap & Bloomberg \\
ERR & Economic Risk Rating & Obtained from the ICRG dataset \\
FRR & Financial Risk Rating & Obtained from the ICRG dataset \\
PRR & Political Risk Rating & $\begin{array}{l}\text { Computed by Principal Component Analysis method using twelve } \\
\text { different political risk components for Turkey obtained from the } \\
\text { ICRG dataset. }\end{array}$ \\
\hline
\end{tabular}

Table 2 presents unit root test results for CDS, ERR, FRR and PRR variables. According to all unit root test results in Table 2, FRR is level stationary, while CDS, ERR and PRR variables are stationary at first differences. Hence, we can say that CDS, ERR and PRR variables are I(1) variables, while FRR series is an I(0) variable.

Table 2: Unit Root Test Results

\begin{tabular}{|c|c|c|c|c|c|c|c|}
\hline & \multicolumn{2}{|c|}{ ADF } & \multicolumn{2}{|c|}{ PP } & \multicolumn{2}{|c|}{ KPSS } & \multirow{2}{*}{ Decision } \\
\hline & Level & $\begin{array}{c}\text { First } \\
\text { Difference }\end{array}$ & Level & $\begin{array}{c}\text { First } \\
\text { Difference }\end{array}$ & Level & $\begin{array}{c}\text { First } \\
\text { Difference }\end{array}$ & \\
\hline CDS & $-2,368$ & $-15,591^{* * *}$ & $-2,401$ & $-15,658^{* * *}$ & $1.215^{* * *}$ & 0,084 & $\mathrm{I}(1)$ \\
\hline ERR & $-1,758$ & $-11,202^{* * *}$ & $-3,144^{* *}$ & $-17,617^{* * *}$ & $1.418^{* * *}$ & 0,080 & $\mathrm{I}(1)$ \\
\hline FRR & $-3.310^{* *}$ & $-17,736^{* * *}$ & $-4.429^{* * *}$ & $-17.822^{* * * *}$ & 0.135 & 0,016 & $\mathrm{I}(0)$ \\
\hline PRR & -1.554 & $-17,369^{* * *}$ & -2.279 & $-17,453^{* * * *}$ & $0.765^{* * *}$ & 0,062 & $\mathrm{I}(1)$ \\
\hline
\end{tabular}

Note: $* * *, * *$ and $*$ denote the rejection of the $\mathrm{H}_{0}$ null hypothesis at $1 \%, 5 \%$ and $10 \%$ significance levels respectively. For the KPSS test, $\mathrm{H}_{0}$ null hypothesis indicates that the series is stationary, while $\mathrm{H}_{1}$ alternative hypothesis indicates that the series is non-stationary.

The unit root test results indicate that we can use ARDL or NARDL models to investigate the effects of economic, financial and political risks on Turkey's CDS. Table 3 reveals bounds test results proposed by Pesaran et al. (2001). The test results in Table 4 indicate that there is a longrun cointegration relationship between CDS premium and economic, financial and political risk variables (i.e. ERR, FRR and PRR).

Table 3: Bounds Test Results for Cointegration

\begin{tabular}{|c|c|c|c|c|}
\hline \multirow[t]{2}{*}{ Dependent Variable } & \multirow[t]{2}{*}{ F statistic } & \multicolumn{2}{|c|}{ Bounds critical value $^{\dagger}$} & \multirow[t]{2}{*}{ Outcome } \\
\hline & & $\mathrm{I}(0)$ & $\mathrm{I}(1)$ & \\
\hline$C D S=f(E R R, F R R, P R R)$ & $5.064^{*}$ & 3.23 & 4.35 & Cointegration \\
\hline
\end{tabular}

Note: ${ }^{\dagger}$ Critical values at 5\% significance level with $\mathrm{k}=3$ are taken from Pesaran et al. (2001) with unrestricted intercept and no trend. ${ }^{*}$ indicates the rejection of no cointegration at $5 \%$ significance level. 
The Wald test in Table 4 tests the null hypothesis of long-run symmetry against the alternative of long-run asymmetry between CDS and ERR, FRR and PRR variables in the NARDL model. The Wald test results in Table 4 indicate that the ERR variable has significant asymmetric effect on the CDS premium in the long-run, while the FRR and PRR variables have no significant asymmetric effects on the CDS premium of Turkey in the long-run.

Table 4: Wald Test Results.

\begin{tabular}{lc}
\hline Variables & Long-run asymmetry \\
\hline$E R R$ & $6.1859(0.0137)$ \\
$F R R$ & $2.1767(0.1401)$ \\
$P R R$ & $0.9155(0.3387)$ \\
\hline
\end{tabular}

Note: Figures in parenthesis are the p-values for the Wald test.

Table 5: The Estimation Results of NARDL model for the CDS Equation.

\begin{tabular}{|c|c|c|c|c|}
\hline Variable & Coefficient & Std. Error & t-statistic & $\mathrm{p}$-value \\
\hline $\mathbf{C}$ & 3.314856 & 0.927906 & 3.572414 & 0.0004 \\
\hline LCDS(-1) & -0.249064 & 0.042932 & -5.801414 & 0.0000 \\
\hline LERR_P(-1) & 0.564091 & 0.301046 & 1.873770 & 0.0624 \\
\hline LERR_N(-1) & 0.932341 & 0.232882 & 4.003494 & 0.0001 \\
\hline LFRR_P(-1) & 0.779029 & 0.230482 & 3.380005 & 0.0009 \\
\hline LFRR_N(-1) & 0.588365 & 0.223183 & 2.636243 & 0.0090 \\
\hline LPRR(-1) & 0.538804 & 0.245198 & 2.197427 & 0.0291 \\
\hline DLERR_P & 0.946676 & 0.467109 & 2.026671 & 0.0440 \\
\hline DLERR_P(-1) & -1.050213 & 0.530563 & -1.979431 & 0.0491 \\
\hline DLERR_P(-2) & -1.436289 & 0.566431 & -2.535680 & 0.0120 \\
\hline DLERR_P(-3) & -0.727630 & 0.360303 & -2.019493 & 0.0448 \\
\hline DLERR_P(-4) & -0.669870 & 0.347042 & -1.930225 & 0.0550 \\
\hline DLERR_P(-5) & -1.041274 & 0.316536 & -3.289590 & 0.0012 \\
\hline DLERR_P(-6) & -1.140986 & 0.315345 & -3.618212 & 0.0004 \\
\hline DLERR_P(-7) & -0.949646 & 0.399908 & -2.374661 & 0.0185 \\
\hline DLERR_P(-8) & -0.526290 & 0.374489 & -1.405354 & 0.1615 \\
\hline DLERR_P(-9) & -0.678820 & 0.372865 & -1.820554 & 0.0702 \\
\hline DLERR_N & -0.251340 & 0.461884 & -0.544163 & 0.5869 \\
\hline
\end{tabular}




\begin{tabular}{|c|c|c|c|c|}
\hline DLERR_N(-1) & -0.911924 & 0.441537 & -2.065341 & 0.0402 \\
\hline DLERR_N(-2) & -0.641652 & 0.431559 & -1.486825 & 0.1386 \\
\hline DLERR_N(-3) & -0.315916 & 0.296953 & -1.063859 & 0.2887 \\
\hline DLERR_N(-4) & -0.611377 & 0.292635 & -2.089211 & 0.0380 \\
\hline DLERR_N(-5) & -1.293112 & 0.288443 & -4.483072 & 0.0000 \\
\hline DLERR_N(-6) & -0.384805 & 0.297899 & -1.291729 & 0.1979 \\
\hline DLERR_N(-7) & -0.397676 & 0.296489 & -1.341281 & 0.1814 \\
\hline DLERR_N(-8) & -0.536377 & 0.291496 & -1.840084 & 0.0672 \\
\hline DLFRR_P & 1.969063 & 0.458032 & 4.298962 & 0.0000 \\
\hline \multicolumn{5}{|c|}{ Long-run asymmetric effects on $C D S$} \\
\hline LERR_P & 2.264843 & 1.101837 & 2.055515 & 0.0411 \\
\hline LERR_N & 3.743374 & 0.598412 & 6.255508 & 0.0000 \\
\hline LFRR_P & 3.127823 & 0.784487 & 3.987092 & 0.0001 \\
\hline LFRR_N & 2.362302 & 0.804985 & 2.934591 & 0.0037 \\
\hline LPRR & 2.163315 & 0.929534 & 2.327312 & 0.0210 \\
\hline$R^{2}$ & 0.29 & & & \\
\hline $\bar{R}^{2}$ & 0.22 & & & \\
\hline$\chi_{L M}^{2}$ & $0.5678 \quad[0.7528]$ & & & \\
\hline$\chi_{H}^{2}$ & $22.745 \quad[0.6473]$ & & & \\
\hline$\chi_{R E S E T}^{2}$ & $0.9313[0.3357]$ & & & \\
\hline$\chi_{N}^{2}$ & $23.820 \quad[0.0000]$ & & & \\
\hline$F_{P S S}$ & $6.3288^{* *}$ & & & \\
\hline$W_{S R}$ & $23.484 \quad[0.0000]$ & & & \\
\hline
\end{tabular}

Note: $\chi_{L M}^{2}, \chi_{H}^{2}, \chi_{R E S E T}^{2}$ and $\chi_{N}^{2}$ denote test statistics for serial correlation, heteroscedasticity, functional form (Ramsey's RESET test) and normality, respectively. Figures in brackets are the p-values. $W_{S R}$ denotes the Wald test for short-run symmetry condition. ${ }^{* *}$ denote the rejection of no cointegration at $1 \%$ significance level.

In order to estimate the long-run asymmetrical relationships between the CDS and ERR, FRR and PRR variables for the analyzed period, the NARDL model is estimated. The estimation results are presented in Table 5. Since the positive and negative coefficients of PRR variable have been found 
insignificant in the NARDL estimation, and since the Wald test result in Table 4 strongly rejects the long-run asymmetric effects of PRR variable, we analyzed its symmetric long and short run effects on the CDS premium in the NARDL model. $F_{P S S}$ test statistic in Table 5 indicates that there is a significant cointegration relationship in the estimated NARDL model. ERR and FRR have significant asymmetric effects on the CDS. The estimated long-run coefficients of $E R R^{+}$and $E R R^{-}$are 2.265 and 3.743 respectively. This means that $1 \%$ increase in economic risk is necessary to increase the CDS by nearly $2.3 \%$ for Turkey, while $1 \%$ decrease in economic risk is necessary to decrease the CDS by $3.7 \%$. Hence, the empirical results indicate that the effect of a decrease in economic risk is much larger that the effect of an increase in economic risk on CDS. On the other hand, the estimated long-run coefficients of $F R R^{+}$and $F R R^{-}$are 3.128 and 2.362 respectively. This means that about $1 \%$ increase in financial risk is necessary to increase the CDS by nearly $3.1 \%$, while $1 \%$ decrease in financial risk is necessary to decrease the CDS by nearly $2.4 \%$. As such, the empirical results indicate that the effect of an increase in financial risk is much larger that the effect of a decrease in financial risk on CDS. Therefore, we can conclude that increases in financial risks play a more important role than economic risks in increasing CDS premium. This result is expected since Turkish economy in the analyzed period can be characterized as a fastgrowing economy with predominantly dependent on foreign financing which leaves Turkish economy more fragile against the changing risk appetite of foreign investors (for further readings see Telli et al., 2008; Özatay, 2008; Macovei, 2009; Uygur 2010; Özatay, 2016; Ozer \&Yeldan, 2016; Abioglu et al., 2020). Thus, we can say that the effects of increases in financial risks on CDS spreads are higher than the effects of increases in economic risks for Turkey that is vulnerable to sudden stops. Further, according to the estimation results, decreases in economic risks play more important role than the decreases in financial risks in decreasing Turkey's CDS premium. This result is also expected since implemented economic reform programs in Turkey in the analyzed period have boosted economic growth and decreased macroeconomic risks (Macovei, 2009; Rodrik, 2012). Thus, we can say that decreases in economic risks have tendency to reduce CDS spreads more than the financial recovery.

We found that political risk variable PRR has a significant symmetric effect on CDS premium. The estimated long-run coefficient of PRR is 2.163. This result indicates that a $1 \%$ increase (decrease) in PRR causes $2.16 \%$ increase (decrease) in CDS premium, or a $0.46 \%$ increase (decrease) in PRR causes a $1 \%$ increase (decrease) in CDS premium.

The bottom part of Table 5 presents the diagnostic test results. According to the diagnostic test results, there are no remaining autocorrelation and heteroscedasticity in the estimated model. So we can say that the NARDL model is well specified. Also, the Wald test for short-term symmetry condition indicates that there is short-run asymmetry in the model. Overall, the estimation results reveal the existence of asymmetric effects of ERR and FRR variables on the CDS premium, and the results are consistent with the economic theory. 
Figure 1: Dynamic Multipliers for CDS

a)

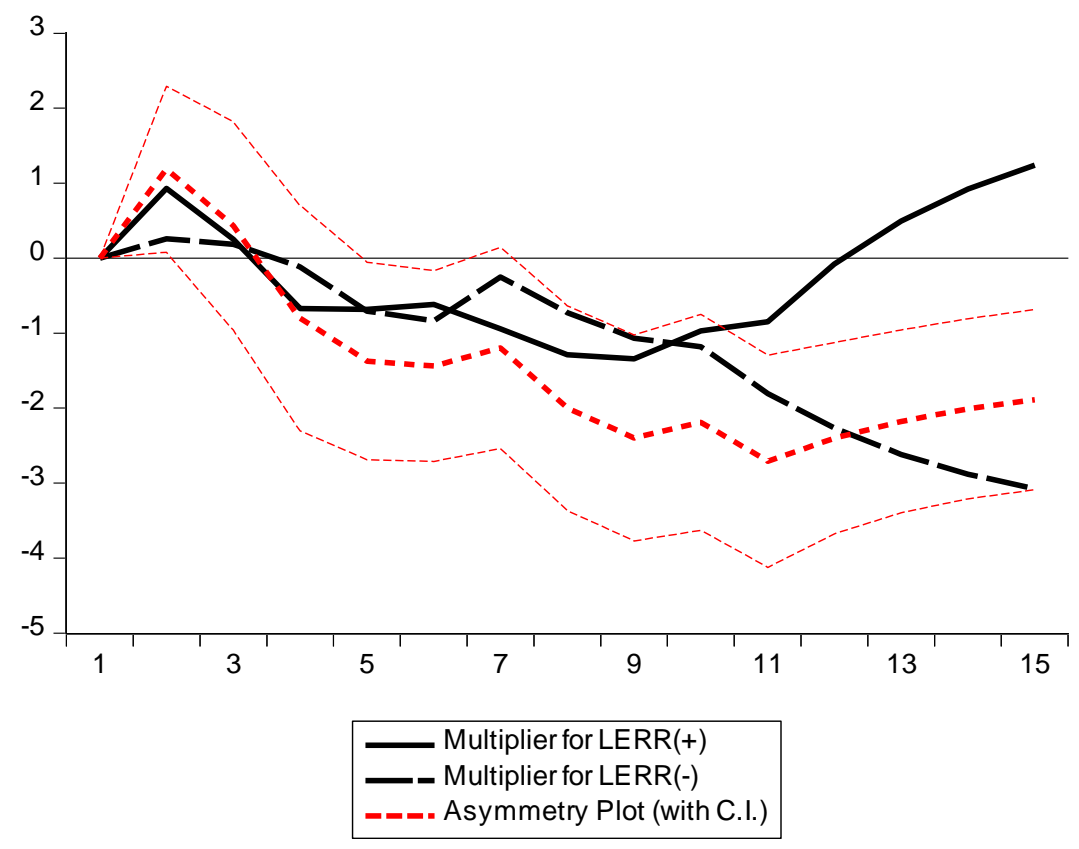

b)

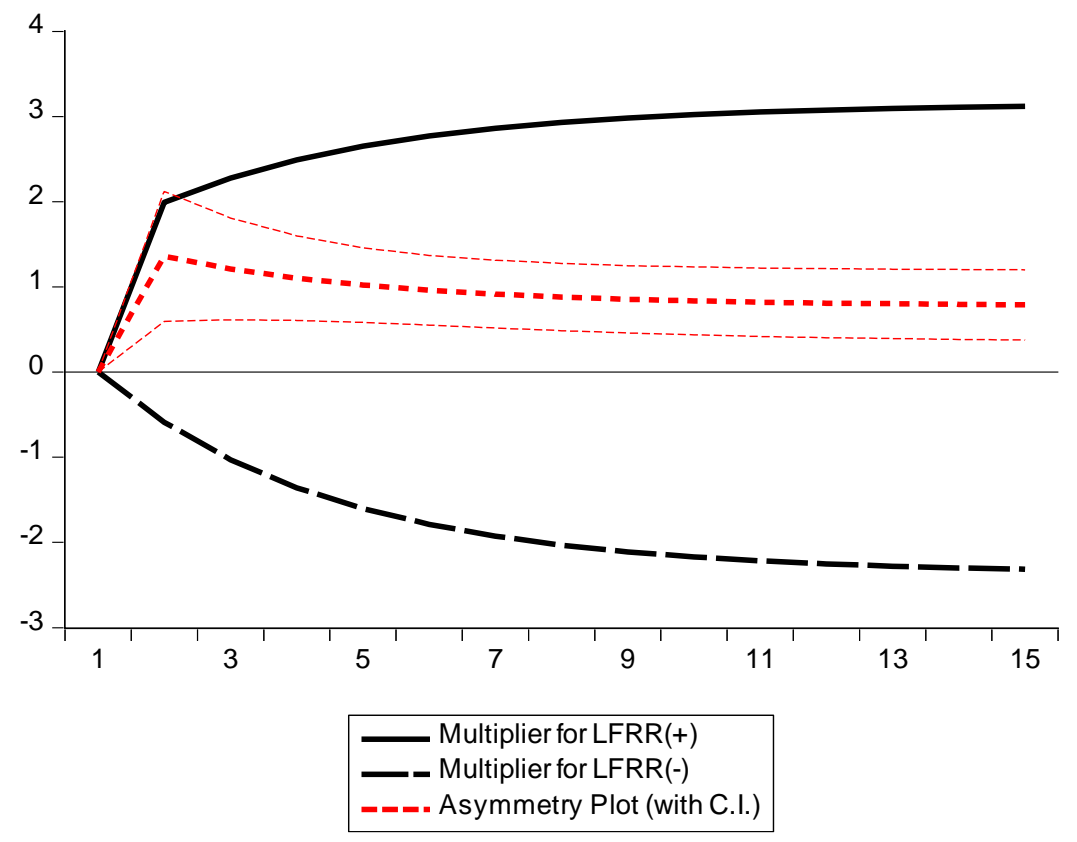

The dynamic multipliers can further summarize and explain the dynamic asymmetric effects of ERR and FRR variables on the CDS premium in the NARDL model. In Figure 1, we observe significant and apparent asymmetries in the adjustment patterns traced by the dynamic multipliers. Figure 1a shows that the long-run response of CDS to positive and negative ERR shocks achieves after 15 months. The asymmetry line in Figure 1a reveals that asymmetric effect of ERR on CDS becomes statistically significant after 5 months. Further, as seen from asymmetry plots of Figure 1a, after 10 months the response of CDS to the negative ERR shocks becomes higher than the response of CDS to the positive ERR shocks. On the other hand, CDS responds rapidly to positive 
FRR changes but full adjustment to the new equilibrium takes nearly 7 months. By contrast, the CDS premium responds mildly to the negative FRR changes and full adjustment is achieved within 10 months. The asymmetry line in Figure $1 \mathrm{~b}$ reveals that there are significant and apparent asymmetry in the response of CDS to positive and negative FRR changes. Hence, we can say that dynamic multiplier plots are compatible with the estimation results of long-run coefficients in the NARDL model.

Figure 2: CUSUM and CUSUM of Squares Test Results

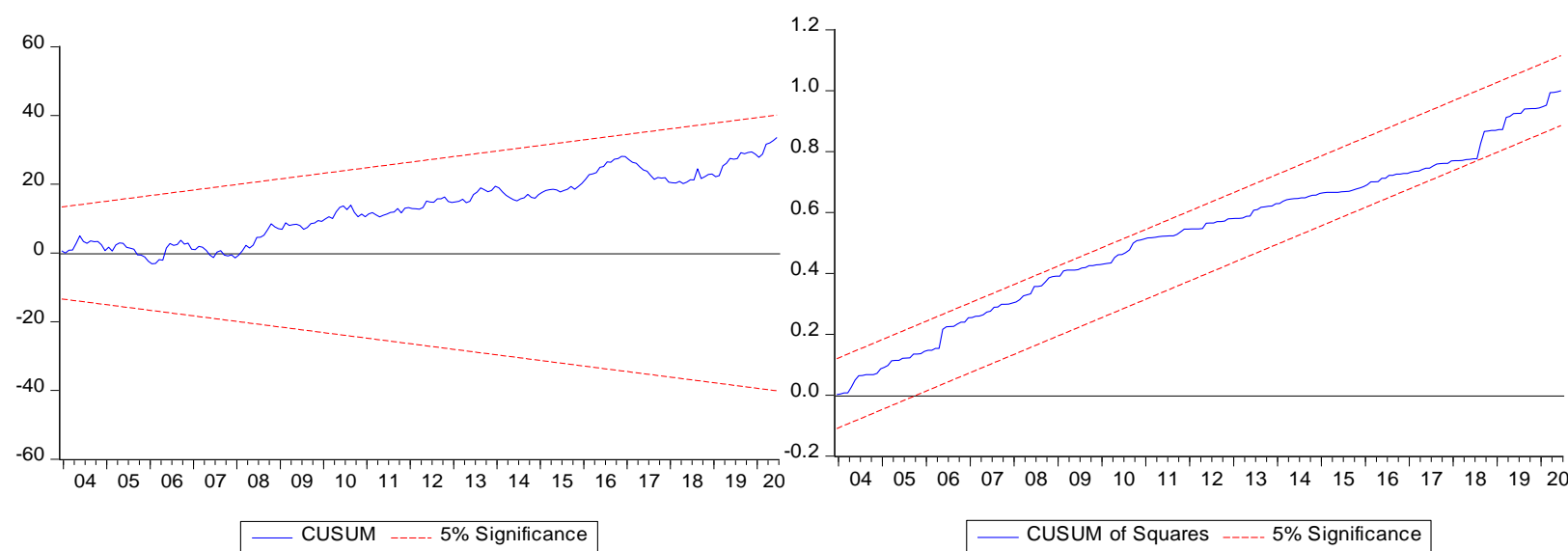

Figure 2 illustrates the CUSUM and CUSUM of squares test results. Both CUSUM and CUSUM of squares test statistics are within the 5\% confidence interval which suggest that the estimated parameters in the model don't include any structural changes.

\section{Conclusion}

Our study analyzes the impacts of economic, financial and political risks on Turkey's CDS for the period 2000:10-2020:06. The findings indicate that the effects of changes in ERR and FRR on Turkey's CDS are asymmetric while the effect of changes in PRR on CDS is symmetric for the period 2000:10-2020:06. We conclude that increases in financial risks play a more important role than economic risks in increasing CDS premium. This result is expected since Turkish economy in the analyzed period can be characterized as a fast-growing economy with predominantly dependent on foreign financing which leaves Turkish economy more fragile against the changing risk appetite of foreign investors. Thus, effects of increases in financial risks on CDS spreads are higher than the effects of increases in economic risks that heighten CDS. Furthermore, we find that decreases in economic risks play a more important role than the decreases in financial risks in decreasing Turkey's CDS premium. This result is also expected since implemented economic reform programs in Turkey in the analyzed period have boosted economic growth and decreased macroeconomic risks. Thus, we can say that the implemented economic reform programs in Turkey in the analyzed period have been more effective than the financial recovery measures in reducing CDS spreads. Hence, the empirical results imply that the economic reforms appear to be more efficient than the financial recovery measures in reducing CDS premium of Turkey.

Yazarlık Katkıları (Authorship Contributions): Vasıf Abioğlu, Munise Ilıkkan Özgür, Esra Soyu

\section{References}

Abioglu, V., Koç S. \& Bakirtas, I. (2020). The sustainability of the Turkish current account: Smooth structural break and asymmetric adjustments. International Journal of Finance \& Economics. DOI: 10.1002/ijfe.1996. Forthcoming.

Aizenman, J., Hutchison, M., \& Jinjarak, Y. (2013). What is the risk of european sovereign debt defaults? Fiscal space, CDS spreads and market pricing of risk. Journal of International 
Money and Finance, 34, 37-59.

Akyol, H., \& Baltacı, N. (2018). Ülke kredi risk düzeyi, petrol fiyatları ve temel makroekonomik göstergelerin hisse senedi getirilerine etkisi: BIST 100 örneği. Kafkas Üniversitesi Sosyal Bilimler Enstitüsü Dergisi, (22), 459-476.

Alexe, S., PL., H., A., K., \& Lejeune, M. A. (2003). A non-recursive regression model for country risk rating. RUTCOR-Rutgers University Research Report, 3, 1-38.

Ashcraft, A. B., \& Santos, J. A. C. (2009). Has the CDS market lowered the cost of corporate debt? Journal of Monetary Economics, 56, 514-523.

Asif, M., \& Majid, A. (2018). Institutional quality, natural resources and FDI: Ampirical evidence from Pakistan. Eurasian Business Review, 8(4), 391-407.

Assane, D. \& Grammy, A. (2003). Institutional framework and economic development: International evidence. Applied Economics, 35, 1811-1817.

Atasever, G. (2017). Türkiye'de risk primi (CDS), piyasa göstergeleri ve seçim dönemlerine ilişkin ekonometrik Analiz. International Journal of Academic Value Studies, 3(13), 217-226.

Ayaydın, H., Pala, F., \& Barut, A. (2016). Ülke riskinin hisse senedi getirisine etkisi: Ampirik bir analiz. Küresel İktisat ve Işsletme Çalışmaları Dergisi, 5(10), 66-75.

Aziz, O. G. (2018). Institutional quality and FDI inflows in Arab economies. Finance Research Letters, 25, 111-123.

Balding, C. (2011). CDS pricing and elections in emerging markets. Journal of Emerging Market Finance, 10(2), 121-173.

Başarır, Ç., \& Keten, M. (2016). Gelişmekte olan ülkelerin CDS primleri ile hisse senetleri ve döviz kurları arasındaki kointegrasyon ilișkisi. Mehmet Akif Ersoy Üniversitesi Sosyal Bilimler Enstitüsü Dergisi, 8(15), 369-380.

Bozkurt, I., \& Kaya, M. V. (2018). Arap bahari coğrafyasindan gelen haberlerin CDS primleri üzerindeki etkisi:Türkiye örneği. Uluslararası İktisadi ve İdari İncelemeler Dergisi -JEAS, $20,1-16$.

Brandorf, C., \& Holmberg, J. (2010). Determinants of sovereign credit default swap spreads for PIIGS: A macroeconomic approach, Lund University. Retrieved May 15, 2020, fromhttp://lup.lub.lu.se/luur/download?func=downloadFile\&recordOId=1608010\&fileOI $\mathrm{d}=1608014$

Busse, M., \& Hefeker, C. (2007). Political risk, institutions and foreign direct investment. European Journal of Political Economy, 23(2), 397-415.

Erb, C. B., Harvey, C. R., \& Viskanta, T. E. (1996). Political risk, economic risk, and financial risk. Financial Analysts Journal, 29-46.

Ersan, İ., \& Günay, S. (2009). Kredi riski göstergesi olarak kredi temerrüt swapları (CDS) ve kapatma davasının Türkiye riski üzerine etkisine dair bir uygulama. Bankacılar Dergisi, (71), 3-22.

European Central Bank (ECB), 2009, Credit Default Swap and Counterparty Risk, Frankfurt. pp.10-59

Filippou, I., Gozluklu, A. E., \& Taylor, M. P. (2018). Global political risk and currency momentum. Journal of Financial and Quantitative Analysis, 53(5), 2227-2259.

Fontana, A., \& Scheicher, M. (2010). An analysis of Euro Area sovereign CDS and their relation 
with government bonds. ECB Working Paper, (12), 5-8.

Günal, M. (2019). Kredi derecelendirme kuruluşlarının rolü ve krizlerdeki etkileri. Ordu Üniversitesi Sosyal Bilimler Araştırmaları Dergisi, 9(1), 147-155.

Hakimi, A., \& Hamdi, H. (2017). Does corruption limit FDI and economic growth? Evidence from MENA countries. Internatıonal Journal of Emerging Markets, 12(3), 550-571.

Harvey, C. R. (2004). Country risk components, the cost of capital, and returns in emerging markets. Retrieved April 17. 2020. from https://ssrn.com/abstract=620710

Hoti, S. (2005). Modelling country spillover effects in country risk ratings. Emerging Markets Review, 6, 324-345.

Howell, L. D. (2011). International country risk guide methodology. East Syracuse, NY: PRS Group.

Howell, L. D., \& Chaddick, B. (1994). Models of political risk for foreign investment and tradean assessment of three approaches. The Columbia Journal of World Business, 70-91.

Huang, W., Lin, S., \& Yang, J. (2019). Institutional quality and sovereign credit default swap spreads. Journal of Futures Markets, 39(6), 686-703.

Kirikkaleli, D. (2020). Does political risk matter for economic and financial risks in Venezuela? Journal of Economic Structures, 9(1), 1-10.

Kılcı, E. N. (2017). CDS primleri ile bir ülkenin ekonomik ve finansal değișkenleri arasındaki nedensellik ilişkisinin değerlendirilmesi: Türkiye örneği. Küresel İktisat ve Işsletme Çalışmaları Dergisi, 12(6), 145-154.

Kunt, A. S., \& Taş, O. (2008). Kredi temerrüt swapları ve Türkiye 'nin CDS priminin tahmin edilmesine yönelik bir uygulama. Itüdergisi/b Sosyal Bilimler, 5(1), 78-89.

Kutuk, T., \& Okur, M. (2020). BRICS-T ülkelerinde risk priminin belirlenmesinde ülke kredi notları ve kredi temerrüt swapı primlerinin karşılaştırmalı analizi. Business and Economics Research Journal, 1(2), 413-429.

Lee, H. H., \& Hyun, J. S. (2019). The asymmetric effect of equity volatility on credit default swap spreads. Journal of Banking and Finance, 98, 125-136.

Lehkonen, H., \& Heimonen, K. (2015). Democracy, political risks and stock market performance. Journal of International Money and Finance, 59, 77-99.

Liu, L., \& Zhong, R. (2017). Political uncertainty and a firm's credit risk: Evidence from the international CDS market. Journal of Financial Stability, (30), 53-66.

Longstaff, F. A., Pan, J., Pedersen, L. H., \& Singleton, K. J. (2011). How sovereign is sovereign credit risk? American Economic Journal: Macroeconomics, 3(2), 75-103.

Macovei, M. (2009). Growth and Economic Crises in Turkey: Leaving Behind a Turbulent Past? European Commission Directorate-General for Economic and Financial Affairs, Economic Papers No.386.

Nawaz, S. (2015). Growth effects of institutions: A disaggregated analysis. Economic Modelling, $45,118-126$.

Özer, M. \& Yeldan A. E. (2016). The relationship between current account deficits and unemployment in Turkey. In Erdoğdu M. M. and Christiansen B. (Eds.), Handbook of research on comparative economic development perspectives on Europe and the MENA region. Hershey, PA: IGI Global. 
Özatay, F. (2008). Expansionary fiscal consolidations: New evidence from Turkey. Economic Research Forum Working Paper Series, Working Paper No: 406.

Özatay, F. (2016). Turkey's distressing dance with capital flows. Emerging Markets Finance and Trade, 52(2), 336-350.

Pesaran, M. H., and Y. Shin. (1999). An autoregressive distributed lag modelling approach to cointegration analysis. In Chapter 11 in Econometrics and Economic Theory in the 20th Century the Ragnar Frisch Centennial Symposium, edited by S. Strom, 371-413. Cambridge: Cambridge University Press.

Pesaran,M. H., Y. Shin, and R. J. Smith. (2001). Bounds testing approaches to the analysis of level relationships. Journal of Applied Econometrics, 16 (3), 289-326.

Plank, T. (2012). Do macro-economic fundamentals price emerging market sovereign CDS spreads? SSRN Electronic Journal, Retrieved 5 May, 2020. from https://doi.org/10.2139/ssrn.1765352

Raunig, B. (2018). Economic policy uncertainty and the volatility of sovereign CDS spreads. Vienna, Austria. Retrieved July 6, 2020. from https://ideas.repec.org/p/onb/oenbwp/219.html

Rodrik, D. (2012). The Turkish economy after the global financial crisis. Ekonomi-Tek, 1(1), 4161.

Shin, Y., Yu, B., \& Greenwood-Nimmo, M. J. (2014). Modelling asymmetric cointegration and dynamic multipliers in a nonlinear framework. In Williams C. Horrace, \& Robin C. Sickles (Eds.), Festschrift in honor of Peter Schmidt Econometric Methods and Applications. 281314. New York (NY): Springer, Science \& Business Media.

Telli, Ç. Voyvoda, E. \&Yeldan, E. (2008). Macroeconomics of twin-targeting in Turkey: A general equilibrium analysis. International Review of Applied Economics. 22(2), 227-242.

Tutar, E., Tutar, F., \& Eren, M. V. (2011). Uluslararası kredi derecelendirme kuruluşlarının rolü, güvenirlilik açısından sorgulanması ve Türkiye. Akademik Bakış Dergisi, (25), 1-24.

Ulusoy, T., \& Kendirli, S. (2019). Türkiye'de gerçekleşen terör saldırılarının olay analizi: VIX korku endeksi, BIST 100 ve kredi temerrüt swapları üzerine etkileri. Insan ve Toplum Bilimleri Araştırmaları Dergisi, 8(2), 1125-1144.

Uygur, E. (2010). The global crisis and the Turkish economy. Turkish Economic Association Discussion Paper, 2010(3), 1-45.

Wisniewski, T. P., \& Lambe, B. J. (2015). Does economic policy uncertainty drive CDS spreads? International Review of Financial Analysis, 42, 447-458.

Yenisu, E., \& Yenice, S. (2018). Temel makroekonomik göstergelerin ülke riski üzerine etkisi: Türkiye örneği. İş ve Hayat Dergisi, 4(8), 27-53. 